\title{
Development of Augmented Spark Impinging Igniter System for Methane Engines
}

\author{
William M. Marshall ${ }^{1}$ \\ NASA Glenn Research Center \\ Cleveland, $\mathrm{OH}$ \\ Robin J. Osborne ${ }^{2}$ \\ ERC, Inc., Jacobs ESSSA Group \\ NASA Marshall Space Flight Center \\ Huntsville, $A L$ \\ and \\ Sandra E. Greene ${ }^{3}$ \\ NASA Marshall Space Flight Center \\ Huntsville, $A L$
}

\begin{abstract}
The Lunar Cargo Transportation and Landing by Soft Touchdown (Lunar CATALYST) program is establishing multiple no-funds-exchanged Space Act Agreement (SAA) partnerships with U.S. private sector entities. The purpose of this program is to encourage the development of robotic lunar landers that can be integrated with U.S. commercial launch capabilities to deliver payloads to the lunar surface. As part of the efforts in Lander Technologies, NASA Marshall Space Flight Center (MSFC) is developing liquid oxygen (LOX) and liquid methane (LCH4) engine technology to share with the Lunar CATALYST partners. Liquid oxygen and liquid methane propellants are attractive owing to their relatively high specific impulse for chemical propulsion systems, modest storage requirements, and adaptability to NASA's Journey to Mars plans. Methane has also been viewed as a possible propellant choice for lunar missions, owing to the performance benefits and as a technology development stepping stone to Martian missions. However, in the development of methane propulsion, methane ignition has historically been viewed as a high risk area in the development of such an engine. A great deal of work has been conducted in the past decade devoted to risk reduction in $\mathrm{LOX} / \mathrm{LCH}_{4}$ ignition. This paper will review and

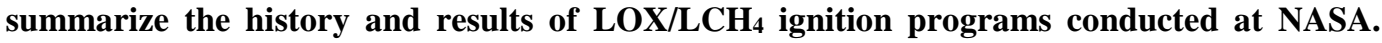
More recently, a NASA-developed Augmented Spark Impinging (ASI) igniter body, which utilizes a conventional spark exciter system, is being tested with $\mathrm{LOX} / \mathrm{LCH}_{4}$ to help support internal and commercial engine development programs, such as those in Lunar CATALYST. One challenge with spark exciter systems, especially at altitude conditions, is the ignition lead that transmits the high voltage pulse from the exciter to the spark igniter (spark plug). The ignition lead can be prone to corona discharge, reducing the energy delivered by the spark and potentially causing non-ignition events. For the current work, a commercial compact exciter system, which eliminates this high voltage cabling, was tested at altitude conditions. A modified, conventional exciter system with an improved ignition lead was also recently tested at altitude conditions. This test program demonstrated the capability of these exciter systems to operate at altitude. While more extensive testing may be required, these systems or similar ones may be used for future NASA and commercial engine programs.
\end{abstract}

\footnotetext{
${ }^{1}$ Chemical and Thermal Propulsion Systems Branch, Senior Member AIAA.

${ }^{2}$ Combustion Devices Design and Development Branch, Senior Member AIAA.

${ }^{3}$ Combustion Devices Design and Development Branch.
} 


\section{Nomenclature}

$\begin{array}{ll}\text { ACS } & =\text { Altitude Combustion Stand } \\ \text { AES } & =\text { Advanced Exploration Systems } \\ \text { ASI } & =\text { Augmented spark impinging } \\ \text { CFD } & =\text { Computational fluid dynamics } \\ \text { GRC } & =\text { Glenn Research Center } \\ \text { HEOMD } & \text { Human Exploration and Operations Mission Directorate } \\ \text { ICPTA } & =\text { Integrated Cryogenic Propulsion Test Article } \\ \text { ISP } & =\text { In-Space Propulsion Facility at Plum Brook Station (formerly: B-2) } \\ \text { JSC } & =\text { Johnson Space Center } \\ \text { MSFC } & =\text { Marshall Space Flight Center } \\ \text { O/F } & =\text { Oxidizer to Fuel mass flowrate ratio } \\ \text { P } & =\text { Chamber pressure } \\ \text { PCAD } & =\text { Propulsion and Cryogenics Advanced Development project } \\ \text { PLC } & =\text { Programmable logic controller } \\ \text { RCE } & =\text { Reaction control engine } \\ \text { RCS } & =\text { Reaction control system } \\ \text { RETF } & =\text { Rocket Engine Test Facility } \\ \text { SAA } & =\text { Space Act Agreement } \\ \text { SBIR } & =\text { Small business innovative research } \\ \text { SPS } & =\text { Sparks per second }\end{array}$

\section{Introduction}

$\mathrm{T}$ HE Lunar Cargo Transportation and Landing by Soft Touchdown (Lunar CATALYST) program is supported by the Lander Technologies project ${ }^{1}$ under the Advanced Exploration Systems (AES) program in NASA's Human Exploration and Operations Mission Directorate (HEOMD). Under the Lunar CATALYST program, NASA is establishing multiple no-funds-exchanged Space Act Agreement (SAA) partnerships with U.S. private sector entities. The purpose of this program is to encourage the development of robotic lunar landers that can be integrated with U.S. commercial launch capabilities to deliver payloads to the lunar surface. There are three commercial partners currently involved in the Lunar CATALYST program.

As part of the efforts in Lander Technologies, NASA Marshall Space Flight Center (MSFC) is developing liquid oxygen (LOX)/liquid methane $\left(\mathrm{LCH}_{4}\right)$ engine technology to share with the Lunar CATALYST partners. Methane propulsion is seen as an attractive technology owing to its relatively high specific impulse for chemical propulsion systems, modest storage requirements, and ability to be obtained from the Martian environment through in-situ resource utilization (ISRU). Additionally, methane has also been viewed as a possible propellant choice for lunar missions, owing to the performance benefits and as a technology development stepping stone to Martian missions.

Within that engine technology development is the need for $\mathrm{LOX} / \mathrm{LCH}_{4}$ igniter systems capable of in-space (vacuum) operation. MSFC is seeking to verify the vacuum ignition capability of their Augmented Spark Impinging (ASI) igniter body for use in the larger $\mathrm{LOX} / \mathrm{LCH}_{4}$ engine development. This igniter body has already seen extensive testing at MSFC, but it has typically been run at sea-level conditions.

Additionally, the desire is to operate this igniter body with a compact-style exciter unit. Conventional-style exciter units have a high-voltage lead that runs from the exciter unit to the spark igniter (spark plug). This highvoltage lead is susceptible to corona discharge at low pressures, thus reducing the power delivered to the spark igniter and risking non-ignition events. ${ }^{2-4}$ Two candidate exciter units have been identified for the current test series; one unit is a compact-style unit, while the second unit is a conventional-style unit that has an improved seal around the high-voltage lead. Neither unit has been tested in vacuum under operational conditions. In seeking to test the ASI igniter body and verify the vacuum worthiness of the candidate exciter units, MSFC sought the capabilities of the NASA Glenn Research Center (GRC) Altitude Combustion Stand (ACS). The ACS facility is capable of testing rocket engines and components up to $2000-\mathrm{lb}_{\mathrm{f}}$ class at simulated altitude conditions up to around 100,000 $\mathrm{ft}$. ( 0.2 psia/10 Torr).

\section{Brief History of Methane Spark Ignition Work at NASA}

Numerous test efforts have been conducted to examine the ignition behavior of oxygen/methane propellants. ${ }^{5}$ This review of prior work will focus specifically on NASA efforts looking at spark ignition. Other efforts by commercial entities or other ignition methods (glow plug, microwave, etc.) are specifically excluded from this 
review. Within NASA programs, two major styles of igniters are discussed. The first style is referred to here as a "single-chamber" design, where both propellants are injected and mixed into a combustion chamber, and the combustible mixture is ignited with a spark igniter (typically an automotive style or surface-discharge style spark plug) that arcs against itself. In this case, the spark energy is directly used to ignite the combustible mixture. Figure 1 shows a representation of this type of igniter. The second style of igniter employs an injection of oxidizer upstream of the spark igniter tip. The oxygen flows past the spark, creating an oxygen plasma which then flows past the spark igniter tip and mixes with fuel to create a combustible mixture downstream of the spark igniter tip, where the mixture ignites. In this case, the spark energy is used to generate an oxygen plasma, and the high-temperature oxygen plasma is used to auto-ignite the combustible mixture. This will be referred to as a "plasma-assisted igniter". Typically the spark igniter for the plasma-assisted igniter has a longer center electrode which arcs against the igniter body, as opposed to a grounding electrode on the spark igniter (spark plug) itself. Figure 2 shows a representation of this style igniter. A brief summary of NASA LOX/LCH 4 spark igniter studies follows. Table 1 summarizes the various igniter programs.

Hurlbert et al. ${ }^{4}$ investigated $\mathrm{LOX} / \mathrm{LCH}_{4}$ for RCS applications by testing a commercially developed LOX/ethanol igniter assembly from an $870-\mathrm{lb}_{\mathrm{f}}(3870-\mathrm{N})$ engine, using $\mathrm{LOX} / \mathrm{LCH}_{4}$. The hardware examined was originally developed as a non-toxic/high performance upgrade for the Space Shuttle Reaction Control System (RCS), and originally used liquid oxygen/ethanol. ${ }^{6}$ This engine was successfully previously tested at the commercial vendor's test facility over a broad range of operating conditions, operating in $870-\mathrm{lb}_{\mathrm{f}}(3870-\mathrm{N})$ primary and $25-\mathrm{lb}_{\mathrm{f}}(111-\mathrm{N})$ vernier modes. The igniter design was a plasma-assisted design. Reliable ignition with methane propellants was demonstrated in 733 hot-fires, over a variety of propellant inlet conditions. Some non-lights were identified to be caused by corona issues due to leakage of the sealed high voltage cable. Additionally, propellant flow during the start transient phase was also identified as a critical factor. An oxygen lead was identified as a preferred condition.

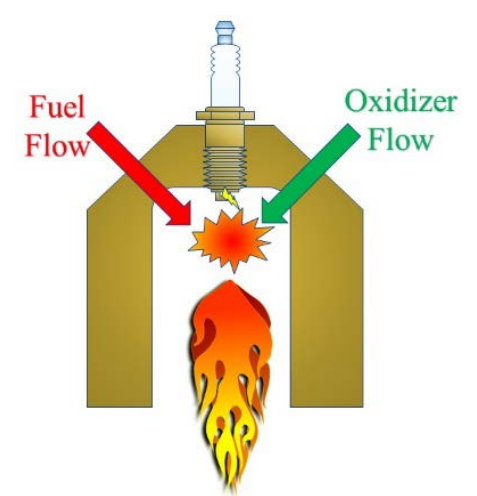

Figure 1: Single chamber style igniter

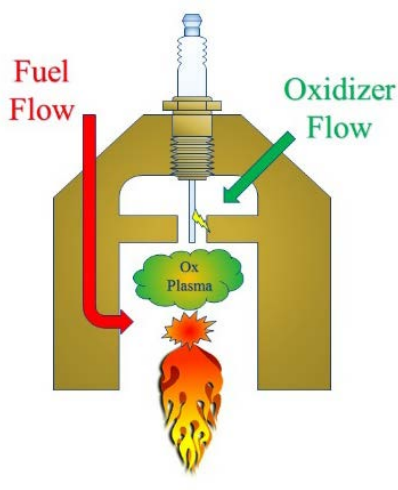

Figure 2: Plasma-Assisted style igniter

Schneider et al. ${ }^{7}$ examined methane/oxygen ignition at altitude utilizing an in-house NASA developed workhorse igniter at NASA GRC. This igniter was a plasma-assisted design. The spark exciter unit for the igniter delivered 200 sparks per second (SPS) at $20 \mathrm{kV}$ and 70 to $150 \mathrm{~mJ}$. Several types of tests were conducted. The first were "performance" tests, where liquid propellants (90 K oxygen and $112 \mathrm{~K}$ methane) were injected into ambient temperature $(298 \mathrm{~K})$ hardware, and the mixture ratio (or oxidizer-to-fuel mass flowrate ratio (O/F)) was varied. Mixture ratio targets were varied from 15 to 31 in the core, and 1.1 to 3.0 overall. Tests were $0.5 \mathrm{~s}$ duration single pulses, and were conducted with a fuel lead of $20 \mathrm{~ms}$ over the oxidizer. The durability tests demonstrated reliable and repeatable ignition over the range of $\mathrm{O} / \mathrm{F}$ tested. Additionally, this test series examined the propellant storage variation, to determine if propellants remained in liquid phase going into the igniter manifold. Tests showed propellants transitioned to vapor phase for ambient temperature hardware. Some non-ignitions were observed, and in general these were attributed to a lack of fuel due to clogging or freezing within the hardware. Ignitions also became more difficult as hardware chilled close to liquid methane temperature $(112 \mathrm{~K})$. Another test series examining hardware durability demonstrated reliable, repeatable ignition over hundreds of pulses. Testing was ultimately halted due to failure of the spark igniter ceramic insulator after 1402 accumulated ignitions.

Breisacher and Ajmani ${ }^{8}$ conducted altitude tests and modeling of a NASA in-house designed oxygen/methane igniter. The igniter was a single-chamber style. A low tension spark igniter was used to ignite the propellants. The spark igniter was mounted in the center of the igniter and for most tests was flush with the top face of the igniter. A variable spark energy (0.007 to $0.55 \mathrm{~J}$ ) and spark rate (153 to $196 \mathrm{SPS}$ ) exciter was used to fire the spark 
igniter. A series of tests were conducted with the GRC igniter design to find the ignition boundaries of liquid oxygen/methane ignition in simulated lunar conditions (i.e. vacuum and cold soaked hardware) and provide data to develop CFD-based methane igniter models. The first test series explored the ignition boundaries without the effects of cold soaking the igniter hardware, from mixture ratios of 0.9 to 10.1. This test series utilized gaseous propellants. The tests had a long blow down duration $(\sim 250 \mathrm{~ms})$ to establish a steady flow field in the igniter before the spark igniter was fired. Results showed reliable ignition down to a mixture ratio of $\sim 1.5$. The next test series explored the effect of having cold igniter hardware on the ability to ignite. Although a flight ignition system may employ an igniter body heater, the cold igniter testing was performed to gauge how much heating must be provided and to see how well the igniter would perform in the absence of a heater. The spark energy for these tests was typically $250 \mathrm{~mJ}$ at 153 sparks per second (SPS). The valve sequence provided a smaller pilot flow for both propellants before the main igniter flow was obtained. Pilot flow mixture ratios ranged from 0.82 to 5.24 near the head-end of the igniter. The lowest igniter body temperatures at which ignition could be obtained for the cases with liquid propellants at the valve inlets is higher than those tests with cold gas at the valve inlets (194 K vs.156 K). Test series with the same operating set conditions were also performed to gauge the effect of a particular operating parameter (i.e. spark igniter power, energy per spark, spark igniter recess, methane purity, and nozzle backpressure) on the cold igniter wall ignition characteristics. Tests showed spark igniter recess was the most critical parameter affecting ignition. Methane purity did not significantly impact ignition.

Kleinhenz et al. ${ }^{9}$ studied ignition within a commercially developed $100-\mathrm{lb}_{\mathrm{f}}(445-\mathrm{N})$ reaction control engine (RCE) with an integrated igniter. While not strictly an igniter-only test, these tests focused on the impact of varying spark power and timing relative to igniter flows. The RCE employed a plasma-assisted style igniter integrated into the main injector. Propellants were introduced with a $10 \mathrm{~ms}$ liquid oxygen lead, with the spark commanded on $10 \mathrm{~ms}$ prior to the liquid oxygen, for a duration of $0.6 \mathrm{~s}$. Various exciter units were tested to examine the impact of spark rate, spark energy, and timing relative to propellant flows. The overall goal of testing was to identify the minimum spark energy required to successfully and reliably ignite the RCE engine. Testing emphasized that propellant flow past the spark igniter impacts spark characteristics (i.e. inconsistent spark energies in flowing conditions). As igniter pressure and flow rate increased during progression of each spark train, spark discharge voltages tended to increase and result in shorter spark durations. This indicates that rising pressures and flow rates substantially increase spark impedance, which, at some point, can affect an exciter's ability to complete sparks without quench. While spark energy was found to exhibit a significant influence on reliability, no distinct minimum spark energy for reliable ignition was found. Rather, ignition displayed a stochastic dependence on spark energy. While higher spark energies were observed to increase ignition probability, spark timing and repetition rate also played a critical role. Lower energy sparks that were well timed with respect to propellant entry often achieved ignition. Higher spark rates, with several sparks over the optimum time interval, also were necessary to ensure an adequate cumulative probability of ignition.

In addition to the works cited above, a number of additional spark ignition work was conducted as part of the Propellants and Cyrogenics Advanced Development (PCAD) Program. Smith et al. ${ }^{5}$ report that ignition risk reduction efforts during PCAD were able to demonstrate the successful operation of a oxygen/methane spark torch igniter to >30,000 ignition cycles. While the broad scope of PCAD work did not observe any issues with hardware or designs for long duration applications, some tests did see issues with spark plug durability and reliability of exciter units under vacuum. ${ }^{4,5}$ Effort during PCAD also examined the development of compact exciter units which would replace the exciter box and high voltage lead to the spark plug. ${ }^{5,}{ }^{10}$ Exciter units developed by commercial vendors as well as Small Business Innovative Research (SBIR) ventures were tested. Extensive igniter testing was also conducted at NASA MSFC which focused on a variety of igniter types. ${ }^{11}$ These MSFC tests efforts eventually led to the development of the current iteration of the MSFC Augmented Spark Impinging (ASI) igniter design which has seen extensive use through a number of MSFC main engine test programs.

The Morpheus project also did some ignition work, first started under the PCAD project, as part of the larger program effort. Specifically looking at developing a reaction control system for Morpheus, work at Johnson Space Center ${ }^{3,12,13}$ investigated ignition of an in-house designed RCS engine, developed from the 870-lb $(3870-\mathrm{N})$ RCS work by Hurlbert et al. ${ }^{4}$ This in-house designed RCS engine utilized an integrated igniter, and was developing a coil-on-plug compact-style exciter system. Ground and flight tests showed successful firing of the RCS engines using the new igniter, and the system was later demonstrated as part of the Integrated Cryogenic Propulsion Test Article (ICPTA) in vacuum condtions, with the coil-on-plug exciter, earlier in 2017 as part of a vacuum facility operations test at NASA GRC’s In-Space Propulsion (ISP, formerly: B-2) facility at Plum Brook Station. ${ }^{14-18}$ 
Table 1: Summary of NASA igniter test programs

\begin{tabular}{|c|c|c|c|}
\hline Igniter Program & $\begin{array}{l}\text { Igniter } \\
\text { Developer }\end{array}$ & Reference Paper & Igniter Type \\
\hline $\begin{array}{l}\text { 870-lbf }(3870-\mathrm{N}) \\
\mathrm{LOX} / \mathrm{LCH}_{4} \mathrm{RCE}\end{array}$ & Commercial & $\begin{array}{l}\text { Hurlbert et al. (AIAA 2008-5247) } \\
\text { Robinson et al. (AIAA 2005-4457) }\end{array}$ & Plasma-Assisted \\
\hline GRC Workhorse Igniter & NASA GRC & Schneider et al. (NASA TM 2007-215038) & Plasma-Assisted \\
\hline $\begin{array}{l}\text { LOX/Methane Main } \\
\text { Engine Igniter }\end{array}$ & NASA GRC & Breisacher and Ajmani (AIAA-2008-4757) & Single Chamber \\
\hline $\begin{array}{l}\text { 100-lbf }(445-\mathrm{N}) \\
\mathrm{LOX} / \mathrm{LCH}_{4} \mathrm{RCE}\end{array}$ & Commercial & $\begin{array}{l}\text { Kleinhenz et al. (NASA TM 2012-217611) } \\
\text { Marshall et al. (NASA TM 2012-217613) }\end{array}$ & Plasma-Assisted \\
\hline $\begin{array}{l}\text { PCAD Ignition Risk } \\
\text { Reduction }\end{array}$ & $\begin{array}{l}\text { Various } \\
\text { (GRC/MSFC/ } \\
\text { Commercial) } \\
\end{array}$ & $\begin{array}{l}\text { Smith et al. (AIAA 2010-8680) } \\
\text { Brown et al. (Space Propulsion 2016) } \\
\text { Robinson (Space Propulsion 2010) }\end{array}$ & $\begin{array}{l}\text { Single Chamber and } \\
\text { Plasma-Assisted }\end{array}$ \\
\hline $\begin{array}{l}\text { Project Morpheus RCS/ } \\
\text { ICPTA }\end{array}$ & NASA JSC & $\begin{array}{l}\text { Hurlbert et al. (AIAA 2011-6113) } \\
\text { McManamen et al. (AIAA 2014-3589) } \\
\text { Hurlbert et al. (AIAA 2016-4681) } \\
\text { Melcher et al. (to be published AIAA 2017) }\end{array}$ & $\begin{array}{l}\text { Plasma-Assisted } \\
\text { (Coil-on-Plug exciter) }\end{array}$ \\
\hline
\end{tabular}

\section{Overview of MSFC ASI Igniter and Exciters}

\section{A. Augmented Spark Impinging (ASI) Igniter}

The Augmented Spark Impinging (ASI) igniter is a NASA in-house developed, plasma-assisted design. The ASI igniter is described as such because it generates a secondary torch flame to ignite a main engine (augmented ignition), uses a spark to create the ignition kernel (spark ignition), ${ }^{19}$ and uses an impinging style injector to deliver and mix the propellants (an impinging igniter). The igniter provides a portion of oxygen flow upstream of the spark igniter tip, and then provides impinging oxygen and methane flows downstream of the spark igniter to create the combustible mixture. Further downstream, additional fuel flow is provided to create a cool barrier to the torch tube and additional mixing and combustion at the end of the torch tube. A pressure tap permits monitoring the igniter chamber pressure during operation. A photograph of the ASI igniter body is shown in Figure 3.

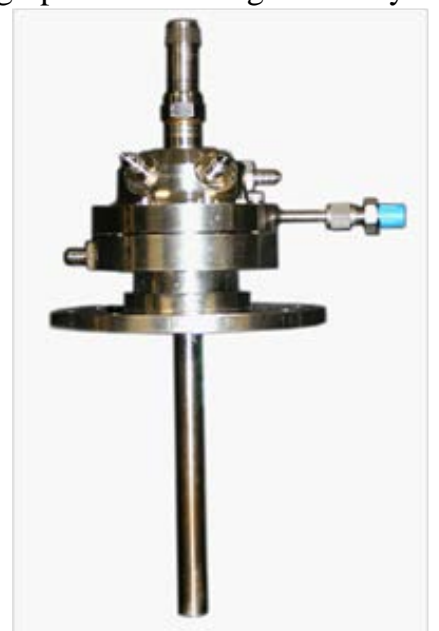

Figure 3: MSFC ASI igniter body

As part of the plasma-assisted design, a small mass flow rate of oxidizer is injected into the spark igniter cavity port and through a downstream annular gap formed by the outer diameter of the spark igniter electrode and the inner diameter of the igniter housing. The flow of oxidizer through the annular gap while the spark igniter is activated allows the hot oxidizer plasma to be swept downstream into the vicinity of the impinging propellants where an ignitable mixture ratio exists. The mixture ratio that exists inside the igniter chamber is referred to as the core O/F. The core $\mathrm{O} / \mathrm{F}\left(\mathrm{O} / \mathrm{F}_{c}\right)$ is defined as follows: 


$$
O / F_{c}=\frac{\dot{m}_{o, s p}+\dot{m}_{o, i}}{\dot{m}_{f, i}}
$$

where $\dot{m}_{o, s p}$ is the mass flow rate of oxidizer past the spark igniter, $\dot{m}_{o, i}$ is the mass flow rate through the oxidizer impinging ports, and $\dot{m}_{f, i}$ is the mass flow rate through the fuel impinging ports. Typically, the ASI is operated with an oxygen-rich condition in the igniter chamber (core O/F).

Once ignition is achieved, the combustion gases are ejected through a nozzle at the end of a torch tube. The nozzle is used to build back pressure within the combustion chamber so that, in the event that a vacuum environment exists outside of the igniter, the spark igniter is able to arc within the pressurized chamber. The $\mathrm{P}_{\mathrm{c}}$ port is located downstream of the spark igniter and between the impinging oxidizer inlets.

Thermal protection of the downstream igniter chamber wall is achieved by using part of the fuel supply as coolant for the torch tube. The coolant fuel is directed down the backside of a liner through a set of channels. These channels empty on the outside and at the exit of the torch tube. Since the mixture ratio (O/F) of the injected core propellants is oxidizer-rich, significant after-burning of the coolant fuel takes place downstream of the torch tube exit. In other words, the excess, oxygen-rich, hot gases flowing out of the torch tube nozzle will burn as a diffusion flame with the co-flow of fuel coolant. The flame front of a diffusion flame, by definition, is where the ratio of the oxygen to fuel is stoichiometric. The output of the ASI igniter is therefore quite robust, with flame temperatures approaching the adiabatic flame temperature downstream of the torch tube exit. The igniter maintains relatively low temperatures internally, while maximizing combustion temperatures downstream of the torch tube, away from the igniter exit. The $\mathrm{O} / \mathrm{F}$ that exists downstream of the torch tube exit is referred to as the global $\mathrm{O} / \mathrm{F}$. The global $\mathrm{O} / \mathrm{F}\left(\mathrm{O} / \mathrm{F}_{g}\right)$ is defined as follows:

$$
O / F_{g}=\frac{\dot{m}_{o, s p}+\dot{m}_{o, i}}{\dot{m}_{f, i}+\dot{m}_{f, \text { cool }}}
$$

where $\dot{m}_{f, c o o l}$ is the mass flow rate of fuel coolant, and other variables are as defined in Eq. (1).

\section{B. Spark Igniter}

The spark igniter used with the ASI igniter is a Champion Aerospace designed spark igniter, shown in Figure 4. The electrode is modified so that the tip extends 1 in. past the shoulder or sealing surface of the spark igniter body. An annular gap is formed between the spark igniter electrode and the ASI igniter body.

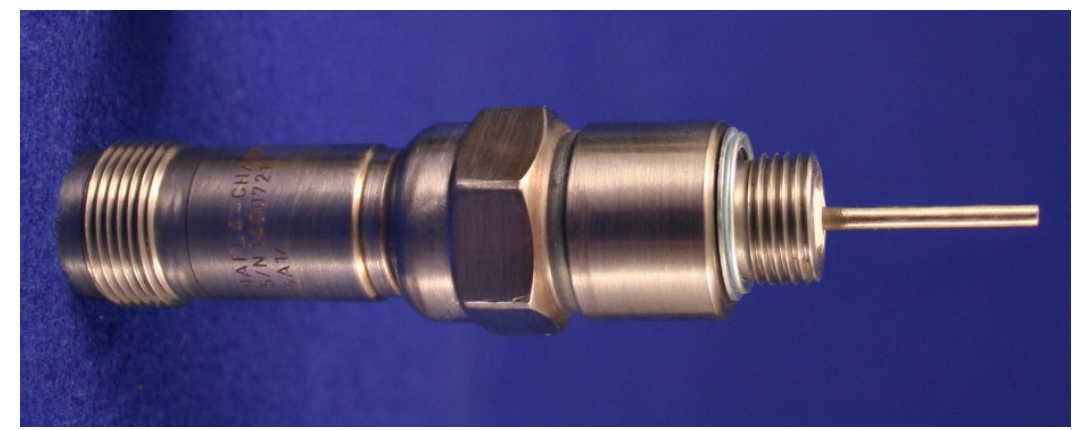

Figure 4: Champion Aerospace spark igniter, OAFL4-Champion-CH31887-3

\section{Exciters}

Two different exciters, both commercially developed, were available for testing with the ASI igniter. The first was a compact-style exciter, while the second was a conventional-style exciter. The two exciters are shown side-byside in Figure 5. Specifications for the two units are listed in Table 2. According to the manufacturer, the conventional-style exciter can be repackaged and utilized as a compact-style exciter. 


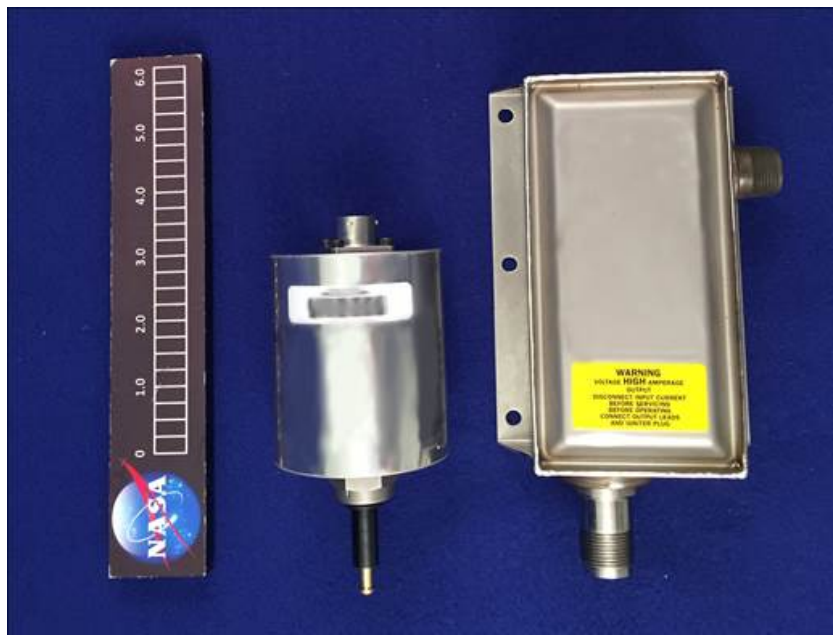

Figure 5: Exciter units tested with ASI igniter

Compact-style unit (left); Conventional-style unit (right, without lead)

In both units, the spark igniter connection is at the bottom

Table 2: Specifications of exciters tested during GRC ASI testing

\begin{tabular}{|l|l|l|}
\hline Style & Compact-Style & Conventional-Style \\
\hline Vacuum Capability & Yes & Yes \\
\hline Potted/Encapsulated Electronics & Yes & Yes \\
\hline Discharge & Magnetic & Capacitive \\
\hline Input Voltage & 24 VDC +/- 1 VDC at 4 A & $26-30 \mathrm{VDC}$ at $2 \mathrm{~A}$ \\
\hline Peak Output & $36-40 \mathrm{kV}$ & $25 \mathrm{kV}$ \\
\hline Stored Exciter Energy & N/A (magnetic discharge) & $125 \mathrm{~mJ}$ \\
\hline Monitor Feedback Signal & Yes & No \\
\hline High Voltage Terminal & ARP670 Type 5M & ARP670 Type 3F \\
\hline Duty cycle & Can run continuously & $30 \mathrm{sec}(\mathrm{max})$ on -2 min off \\
\hline Spark Rate & $200 \mathrm{SPS}$ & $83 \mathrm{SPS}$ \\
\hline Operational Temperature Range & -40 to $+185^{\circ} \mathrm{F}(233$ to $358 \mathrm{~K})$ & -65 to $+250^{\circ} \mathrm{F}(219$ to $394 \mathrm{~K})$ \\
\hline Weight & $1 \mathrm{lb} 2.5 \mathrm{oz}(0.5 \mathrm{~kg})$ & $\begin{array}{l}2 \mathrm{lb} 6.5 \mathrm{oz}(1.1 \mathrm{~kg}) \\
(3 \mathrm{lb} 1 / 2 \mathrm{oz}[1.4 \mathrm{~kg}] \text { with 2 ft. long } \\
\text { ignition lead })\end{array}$ \\
\hline Delivered Spark Energy* & & $50 \mathrm{~mJ}$ \\
\hline
\end{tabular}

* MSFC estimated values based upon measurements of voltage and current in an instrumented ignition lead while sparking in quiescent air. Values are specific to the spark gap geometry used in the ASI igniter.

\section{Test Facility and Setup}

\section{A. NASA Glenn Altitude Combustion Stand (ACS)}

The current series of testing of the ASI igniter was conducted at the NASA Glenn Research Center (GRC) Altitude Combustion Stand (ACS). Detailed descriptions of the facility can be found in the literature. ${ }^{20,}{ }^{21}$ A brief summary description of the facility and its capabilities is provided here. Figure 6 shows a photograph of the exterior systems of ACS, showing the ejector system, spray cart, water-cooled diffuser, and the mobile end of the test capsule. In the background can be seen the hydro-pillar tower which provides the water for the spray cart and water cooled diffuser. 


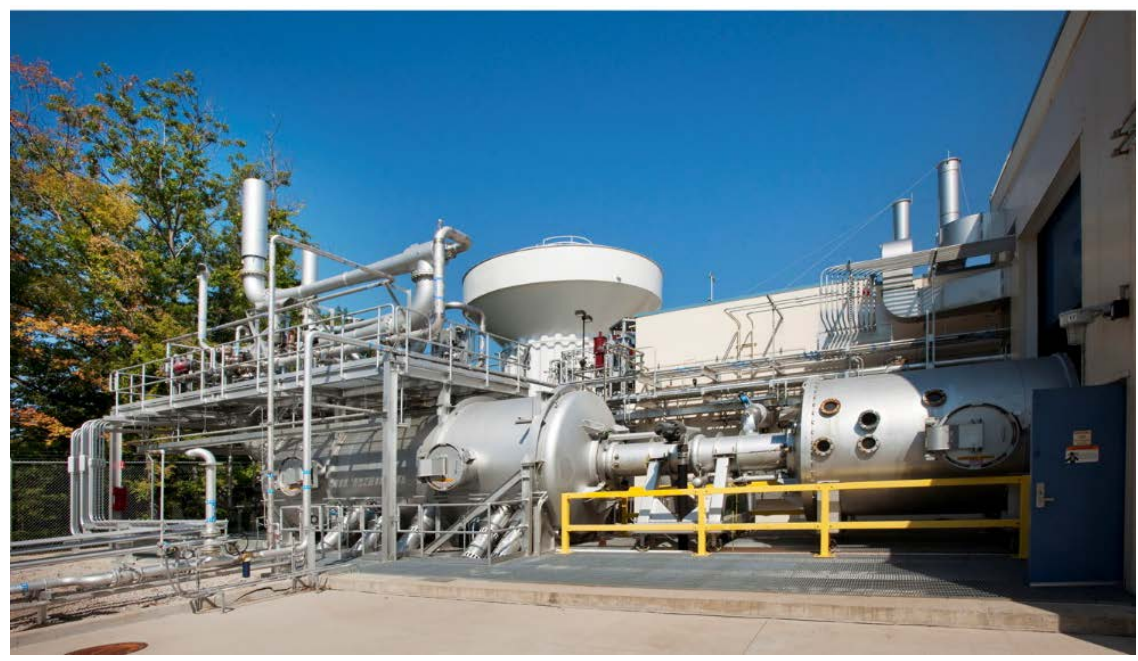

Figure 6: Photo of exterior of GRC Altitude Combustion Stand, showing ejectors, hydro-pillar, spray cart, water cooled diffuser, and mobile end of test capsule

The facility was utilized for extensive testing of the $\mathrm{LOX} / \mathrm{LCH}_{4} 100-\mathrm{lb}_{\mathrm{f}}(445-\mathrm{N}) \mathrm{RCE}$ engine under the Propellants and Cryogenics Advanced Development (PCAD) program. During the course of a year, over 300 hotfire tests were conducted on the RCE under three related but distinct test efforts. ${ }^{5,}$, 10 Figure 7 shows a photograph of RCE testing inside the test capsule during PCAD. Following the PCAD program, the facility was temporarily placed into an inactive status until reactivation of the facility in 2016. A series of check-out tests were conducted to verify all systems were still operational. Since PCAD RCE hardware had remained on the test stand while the facility was inactive, this hardware was the most expedient hardware available and was utilized for the check-out tests during reactivation. As both the RCE and ASI igniter utilized oxygen/methane propellants, an expedient transition was possible between the RCE reactivation tests and ASI igniter in support of the Lander Technologies program.

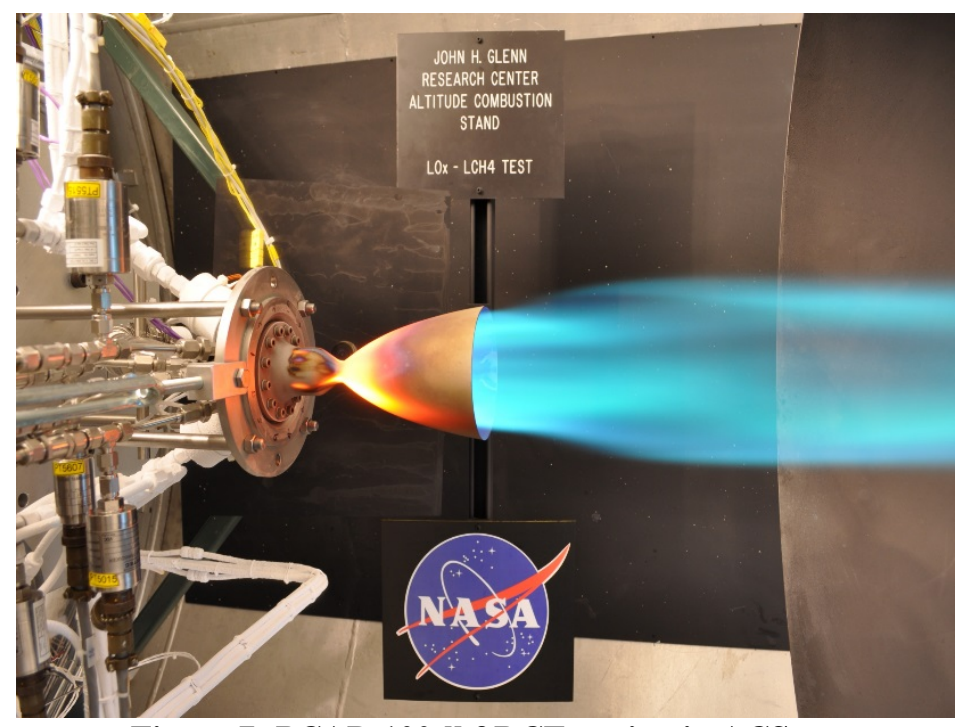

Figure 7: PCAD 100-lbf RCE testing in ACS

The ACS facility is capable of testing engines up to $2000 \mathrm{lb}_{\mathrm{f}}(8896 \mathrm{~N})$, utilizing oxygen, hydrogen, or methane propellants. Propellant conditioning systems, utilized during PCAD testing, provide the capability of delivering LOX and $\mathrm{LCH}_{4}$ at precisely controlled conditions $\left(+/-5{ }^{\circ} \mathrm{R}\right)$ to an engine test article. ${ }^{22}$ The facility is an altitude simulation test stand, with three nitrogen driven ejector trains and one service-air driven ejector that can evacuate the test capsule to a simulated altitude of up to around 100,000 ft. ( $0.2 \mathrm{psia} / 10 \mathrm{Torr})$. The test article is mounted to a fixed end of the test capsule, and the mobile end rolls in and out and seals to the fixed end to create the vacuum 
environment. The facility also has multiple support systems (e.g. helium, nitrogen, etc.) to support rocket engine testing. Command and control data are provided by a programmable logic controller (PLC), with 10 ms resolution. A control room located within the facility provides test operators and research personnel near real-time access to test data, providing for rapid test turn-around as needed, with up to 24 hot-fire tests per day having been achieved to date. The facility is capable of supporting up to 400 channels of data output at $1000-\mathrm{Hz}$ sample rate and can accommodate special research instrumentation (e.g. high frequency data, special imaging, etc.) as required.

\section{B. ASI Igniter Setup}

The NASA MSFC Augmented Spark Impinging (ASI) igniter was tested at the NASA GRC ACS test facility in August 2016. A photograph of the ASI igniter test firing in ACS is provided in Figure 8. The objectives of the current test series were to 1) verify the operation of the two commercial exciter units in a vacuum environment, and 2) explore the operational range of the ASI igniter as time permitted.

The ASI igniter was installed to be operated at the design core mixture ratio of $\sim 40$, with an overall mixture ratio of 5.3, assuming gaseous propellants. Although the ACS propellant conditioning systems are designed to deliver controlled temperature liquid flow, it was believed for this setup the propellants would gasify by the time they reached the igniter. Solenoid valves controlled overall propellant flow, while sonic venturi located downstream of the solenoid valves were used to meter propellant mass flows to the various legs of the ASI, assuming gaseous choked flow. Figure 9 shows a schematic of the propellant feed to the ASI. In the schematic, PT represents locations of pressure transducers and TE represents the location of thermocouples. $\mathrm{GN}_{2}$ purges were located at the junction of the flow splits, (PT5x15 in the schematic). A type-K thermocouple was located just downstream of the igniter torch tube (see Figure 8), and was only used to verify ignition.

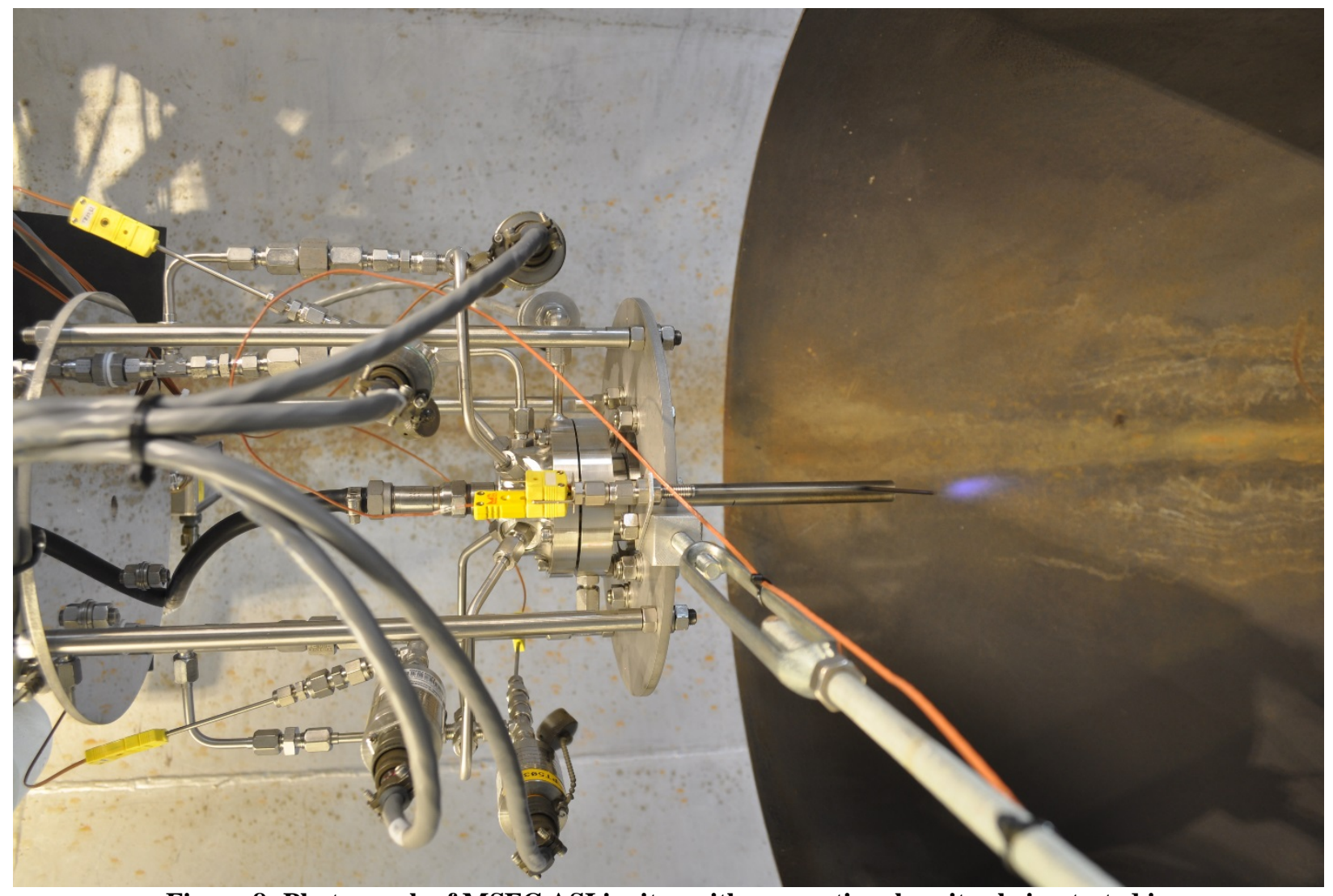

Figure 8: Photograph of MSFC ASI igniter with conventional exciter being tested in GRC Altitude Combustion Stand 


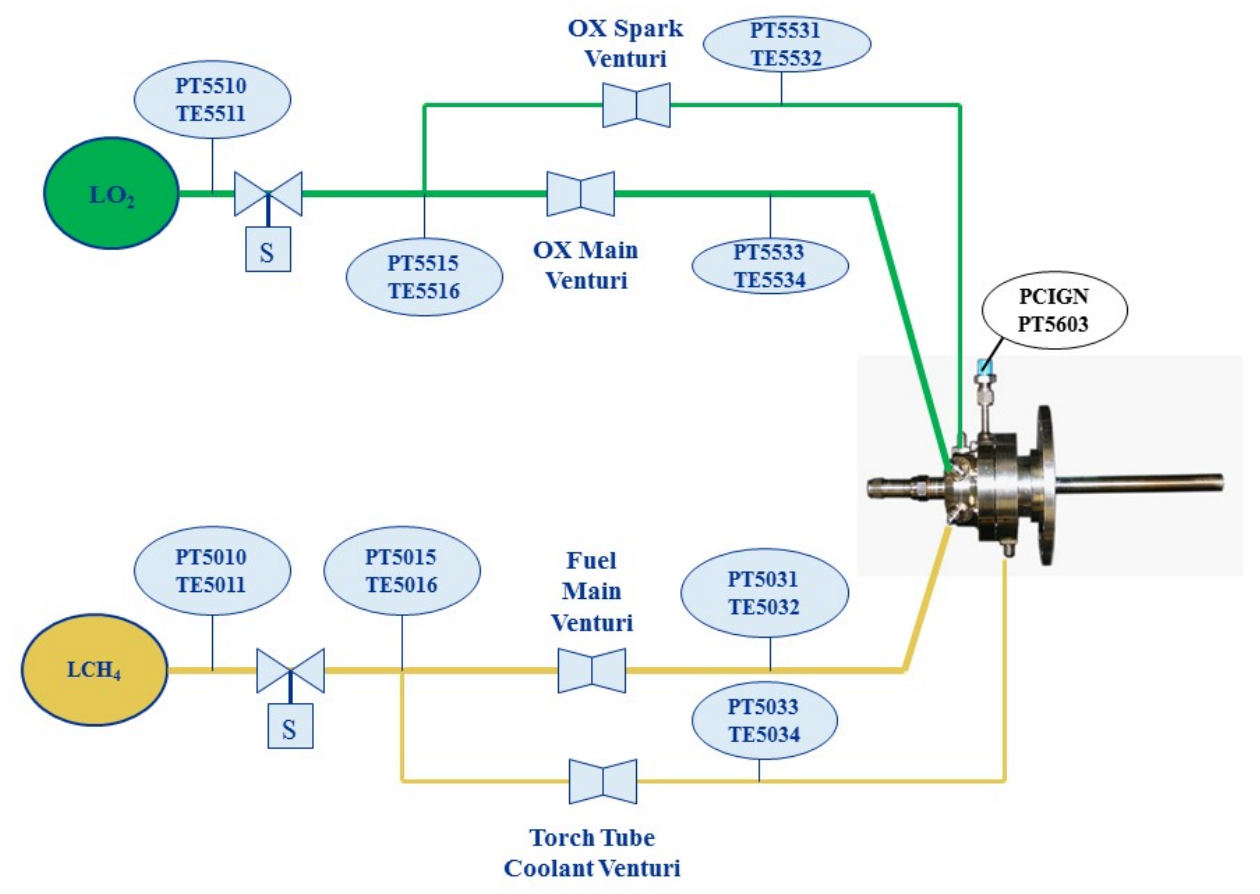

Figure 9: Schematic of propellant feed to ASI Igniter installed at NASA GRC ACS

\section{Results and Discussion}

Over 100 tests were conducted on the MSFC ASI igniter. All tests, with the exception of sea-level tests, were conducted at altitude conditions with a base vacuum pressure of $\sim 0.5$ psia ( 25 Torr). Test conditions are provided in the Appendix (Tables 3-7). The tables identify test day (Day 1, 2, etc.), run number, exciter (compact versus conventional), fuel lag (ms) relative to oxygen flow (negative values indicate fuel preceded oxygen), whether ignition occurred, ignition delay (ms), and target $\mathrm{O} / \mathrm{F}_{\mathrm{c}}$ condition. Finally, the actual $\mathrm{O} / \mathrm{F}_{\mathrm{c}}$ is provided based on actual propellant temperatures just upstream of the sonic venturi. In cases where liquid may have flowed through an orifice, the flowrate calculation assumed liquid through a cavitating venturi.

Timing was initially set to be similar to the timing of the PCAD hardware tests. ${ }^{9}$ The spark was commanded on, followed by the LOX $10 \mathrm{~ms}$ later, and then $\mathrm{LCH}_{4} 10 \mathrm{~ms}$ later. Test duration (1 s) was defined from the time both propellant valves were open until the closure of the LOX valve. A $40 \mathrm{~ms}$ fuel lag on shutdown provided cooling to the hardware post-test. Figure 10 shows a schematic of this timing sequence. In the tables in the Appendix, tests with a fuel lag of $10 \mathrm{~ms}$ correspond to this specific timing sequence. Adjustments to the timing were made by adjusting the LOX timing so that the full test duration of $1.0 \mathrm{~s}$ (defined as both valves open) was maintained. For Test Day 5, the LOX timing was set to come on at $1.00 \mathrm{~s}$ elapsed time and the fuel extended to provide a fuel lead.

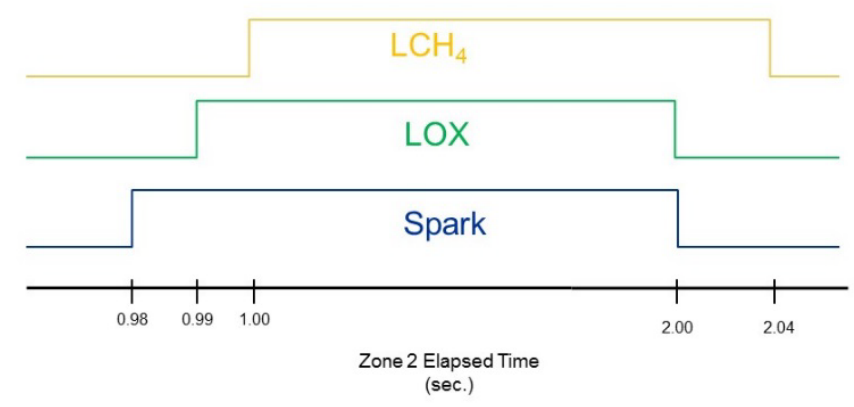

Figure 10: Timing sequence used throughout the majority of test program (unless otherwise noted) 
The first set of tests conducted (Pre-Test - not included in Tables) were exciter only tests as the test capsule was pumped down to a base vacuum pressure of approximately 0.5 psia (25 Torr). Both exciters were tested inside the test capsule, but outside of the ASI igniter body, to obtain visual verification of the spark igniter operating. Both units demonstrated the ability to spark in vacuum down to 0.5 psia (25 Torr). The conventional-style exciter had a much stronger sparking capability than the compact unit, seen in the visible sparks, as was expected from the energy specifications listed in Table 2.

After the exciter-only checkouts, the compact exciter was installed into the ASI igniter body for hot-fire testing. A brief set of check-out tests were performed to check the aborts and timing. Initially an abort was set to trigger if the igniter did not light. However, given the occurance of ignition delay and the small flowrates and durations associated with the igniter, this particular abort redline was eliminated.

The first series of tests (Test Day 1, Table 3) used both exciters, with the propellant conditioning systems actively chilling the propellant lines up to the solenoid valves similar to past PCAD testing. The first exciter unit tested in Test Day 1 was the compact unit. After it failed to achieve ignition at the baseline flow conditions, test conditions were changed to increase the oxygen flowrate to enable the plasma to reach further into the igniter's combustion chamber. During the series of five tests, only a single test achieved ignition. The compact exciter was then swapped out for the conventional exciter, and the tests were repeated. After a series of non-ignitions, which included adjusting propellant timing, the hypothesis was given that perhaps too much oxygen was being used after all, which might over-stretch and weaken the plasma, or possibly, quench the spark. The flowrate of oxygen was thus reduced and successful ignition occurred on the next three sets of tests around a target $\mathrm{O} / \mathrm{F}_{\mathrm{c}}$ of 30 . The LOX flowrate was further reduced, and the final two tests also ignited. Ignition delays were on the order of 140 to $550 \mathrm{~ms}$.

During setup, the belief was the propellant temperatures would rise from the solenoid valves to the igniter hardware such that gaseous propellants would be obtained at the igniter. However, during the Test Day 1 series of tests, the propellant temperatures stayed low at liquid temperatures up to the sonic venturi and the propellants were possibly flowing as liquid through the venturi. The hypothesis could not be ruled out that the propellants were being injected into the igniter as liquids. The operation of the propellant conditioning systems was adjusted to reduce the amount of line cooling so that gaseous conditions could be more readily generated throughout the run lines. Additionally, smaller (1/16 in.[1.5 mm]) Type-E thermocouples were installed into the lines just upstream of the sonic venturi to get faster responses on temperature changes once the propellant valves opened. The addition of the smaller thermocouple would allow more accurate assessment of the fluid conditions just upstream of the venturi.

The next series of tests (Test Day 2, Table 4) focused only on the conventional-style exciter, with emphasis on exploring the operational envelope of the ASI igniter. With the conditioning system operation modified, the liquid propellant in the run tanks was allowed to gasify in the run lines so gaseous propellants were assuredly being delivered to the igniter. Typically these temperatures were between $500-530{ }^{\circ} \mathrm{R}$ as measured at TE5x16, for all remaining tests in the test program. Tests were initially started at the successful $\mathrm{O} / \mathrm{F}_{\mathrm{c}}$ condition from the previous run day $\left(\mathrm{O} / \mathrm{F}_{\mathrm{c}} \sim 30\right)$, and the operation of the ASI igniter was tested from a target $\mathrm{O} / \mathrm{F}_{\mathrm{c}}$ of 30 down to a target $\mathrm{O} / \mathrm{F}_{\mathrm{c}}$ of 23. Fourteen of the 16 tests resulted in ignition. During the last few tests the propellant lines, particularly the methane line, had started to chill in from the liquid supply run tanks and thus cold, dense propellants were observed for the last few tests. Ignition delays for these tests ranged from 120 to $865 \mathrm{~ms}$. Figure 11 shows a plot of the ASI igniter ignition delay vs. the GOX flow into the igniter (PT5533, downstream of venturi). The figure shows the large variability in ignition delay observed, despite relatively stable oxidizer flow rate conditions to the igniter.

Following the conventional-style exciter tests, similar condition tests (Test Day 3, Table 5) were run for the compact-style exciter. Again, tests were started at the successful $\mathrm{O} / \mathrm{F}_{\mathrm{c}}$ condition from Test Day 2 (Target $\mathrm{O} / \mathrm{F}_{\mathrm{c}} \sim 30$ ). Out of 17 attempted tests, 2 were able to successfully ignite but experienced long ignition delays around 840$880 \mathrm{~ms}$. Set pressures were adjusted, first to decrease oxygen flowrate, then to increase oxygen flowrate, then to increase methane flowrate. All tests had similar timing, with a $10 \mathrm{~ms}$ oxygen lead. One ignition occurred at a target $\mathrm{O} / \mathrm{F}_{\mathrm{c}}$ of $\sim 46$, while the other ignition occurred at an $\mathrm{O} / \mathrm{F}_{\mathrm{c}} \sim 40$. Despite the set pressures, actual mixture ratios achieved were lower (33.7 and 34.4) due to run to run variations in temperature conditions of the propellants.

The long ignition delays seen in ACS testing were not in the experience of prior ASI testing at MSFC. In order to better understand the behavior of the igniter, sea-level condition tests were next conducted to provide comparative data to prior MSFC test experience. Test Day 4 (Table 6) examined sea-level operation of the igniter for both the compact and conventional exciter units. The compact exciter was used in the first set of tests and only able to ignite on 3 of 11 attempts. The exciters were switched out, and the conventional unit was then tested, successfully lighting on every attempt, operating from an $\mathrm{O} / \mathrm{F}_{\mathrm{c}}$ of 41.5 down to 25 . Ignition delays were on the order of 400 to $770 \mathrm{~ms}$ for the compact exciter and 115 to $590 \mathrm{~ms}$ for the conventional exciter. 


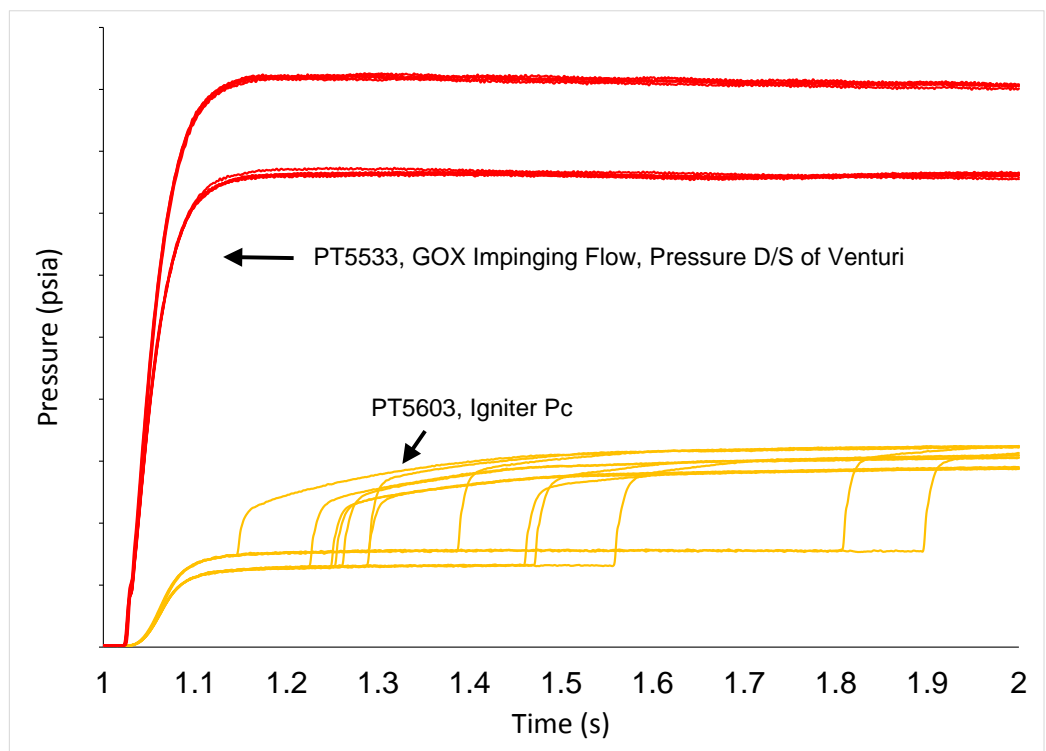

Figure 11: Plot of ignition delay seen in Day 2 testing (GRC tests - ignited test only)

Reviewing some data from prior MSFC testing, the GRC testing was experiencing much more variability in ignition delay than MSFC experienced. A brief discussion of select MSFC data follows for comparison. ASI igniter pressures for two MSFC mainstage engine test series (referred to here as "MSFC Test Series 1" and "MSFC Test Series 2") are shown in Figure 12 and Figure 13. It is worth noting that for these test series, MSFC utilized a $150 \mathrm{~ms}$ fuel lead (as opposed to the ox lead GRC utilized) during operation of the ASI igniter. The significance of this will be made apparent later. For these plots, all test data were re-zeroed for each test to align the initial pressure rise in P5102/P5101 which is the pressure downstream of the venturi that controls the oxidizer flow to the ASI igniter's impinging oxidizer flow. While there is some variability in the ignition delay, the MSFC data shows much greater consistency with ignition delays ranging between 250 to 560 ms for MSFC Test Series 1 and a more consistent 55 ms for MSFC Test Series 2. The ignition delays for MSFC tests are defined as the time from oxidizer manifold pressure rise until ignition within the ASI chamber. However, for GRC data, the delay is counted from the time the ASI combustion chamber pressure first starts to rise (cold flow) until ignition. However, it is still apparent that MSFC timing shows more consistency in ignition delays over GRC tests.

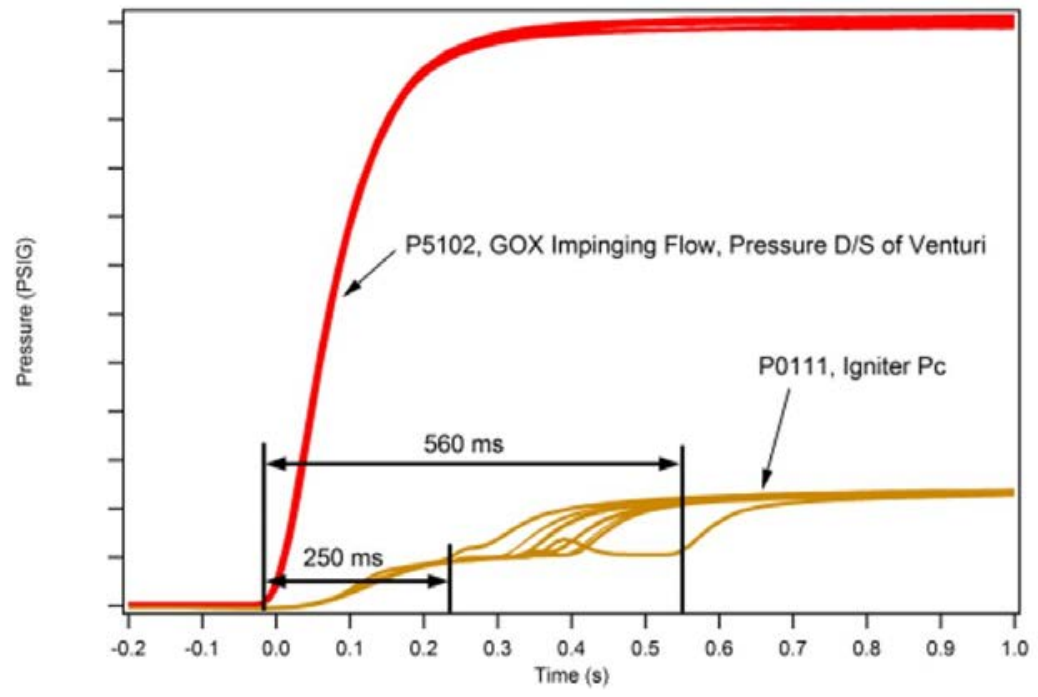

Figure 12: Plot of ASI ignition delays for "MSFC Test Series 1" 


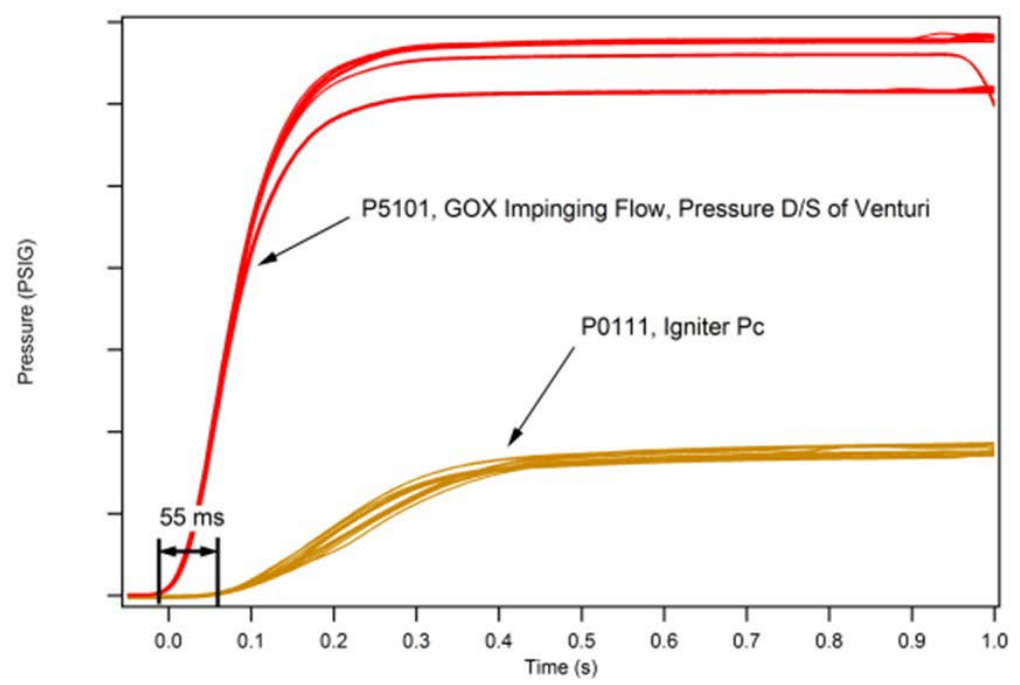

Figure 13: Plot of ASI igntion delays for "MSFC Test Series 2"

Given the discrepancy between GRC and MSFC ignition delay experience, Test Day 5 (Table 7) at GRC sought to gain significant repeatable tests at altitude in order to look for consistency in ignition delay characteristics, similar to those experienced at MSFC. All tests were conducted at similar flow conditions (Target $\mathrm{O} / \mathrm{F}_{\mathrm{c}} \sim 41.5$ ), with the conventional-style exciter unit. The first set of tests, Tests 696 to 702, used the $10 \mathrm{~ms}$ ox lead used previously. These tests ignited for four of the six tests. There is no indication from the data why the non-ignitions occurred, despite all tests being conducted under nearly identical conditions. Ignition delays were on the order of 260-560 ms. Further reviewing results observed in the prior MSFC testing and examining the fuel manifold pressure rise downstream of the sonic venturi during GRC runs, the transient manifold fill process for the igniter may be creating a momentary fuel-starved condition using the ox lead timing, despite having similar $\mathrm{O} / \mathrm{F}_{\mathrm{c}}$ as $\mathrm{MSFC}$ tests. Longer fuel leads were attempted to give more time for fuel to reach the combustion chamber. For remaining tests, only the fuel lag timing was adjusted. Other test conditions remained the same. Figure 14 shows a typical pressure plot of manifold pressures for tests 696 to 702 . The plot shows that the fuel to the combustor (feed line downstream of sonic venturi, PT5031/grey line) is slow to fill and pressurize. From the period $1.0 \mathrm{~s}$ to $\sim 1.1 \mathrm{~s}$, pressure build-up in the fuel manifold is insufficient to overcome the LOX feed (as indicated by $\mathrm{P}_{\mathrm{c}} /$ yellow line being higher pressure than PT5031), leading to a fuel starved condition in the combustor, despite matching $\mathrm{O} / \mathrm{F}_{\mathrm{c}}$ to MSFC testing. This could have caused a transient oxidizer-rich period (well beyond the expected $\mathrm{O} / \mathrm{F}_{\mathrm{c}}$ ) in the combustor which would have been difficult to ignite, thus prompting the ignition delay.

The remaining tests of Test Day 5 progressively increased the fuel lead, up to $150 \mathrm{~ms}$, and subsequently saw decreases in ignition delay times. For these last tests, ignition delays were on the order of 5-320 ms. Figure 15 shows a plot of the combustor manifold pressures for later tests with the $150 \mathrm{~ms}$ fuel lead. From this figure, there is sufficient time for the fuel manifold to pressurize before LOX entry, allowing more favorable ignition conditions to be present, and thus a much shorter ignition delay time. Figure 16 shows a plot of fuel lead vs. ignition delay for these sets of tests. In this figure, error bars on the averages represent $\pm 1-\sigma$ standard deviation in the spread of data at a specific fuel lag condition.

From the tests that focused on ignition delay (Test Day 5), the data clearly show that providing sufficient time for the fuel to enter the manifold is critical to reducing the ignition delay time. Figure 16 shows there is a clear trend in reducing the ignition delay as the fuel lead is increased. At some point, however, this tend is expected to stop as further increasing the fuel timing would lead to an overly fuel-rich condition on start up which would also be unfavorable for ignition. No attempt was made during this test series to further optimize the fuel timing beyond the experience base of MSFC testing.

While ignition for the ASI igniter, a plasma-assisted igniter, is started by an oxygen-only flow past the spark igniter tip, testing confirmed that sufficient fuel is necessary to be present during the transient fill process in order to successfully ignite. Testing demonstrated that relying only on the overall mixture ratio set condition for the igniter is not sufficient to ensure reliable ignition. Even though the oxygen only led the fuel by $10 \mathrm{~ms}$ in earlier tests, for this 


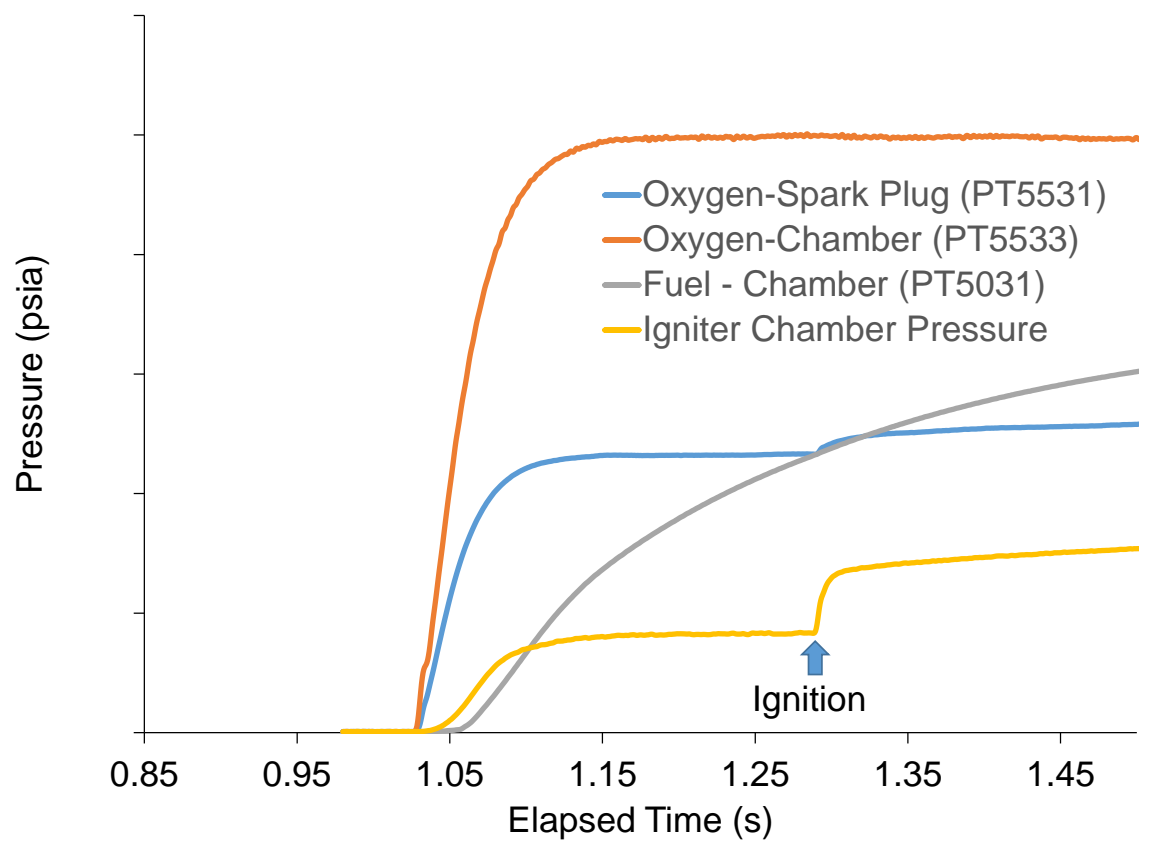

Figure 14: Plot of ASI manifold and chamber pressure vs. time for $10 \mathrm{~ms}$ ox lead timing condition during GRC tests (GRC Tests - Run 698)

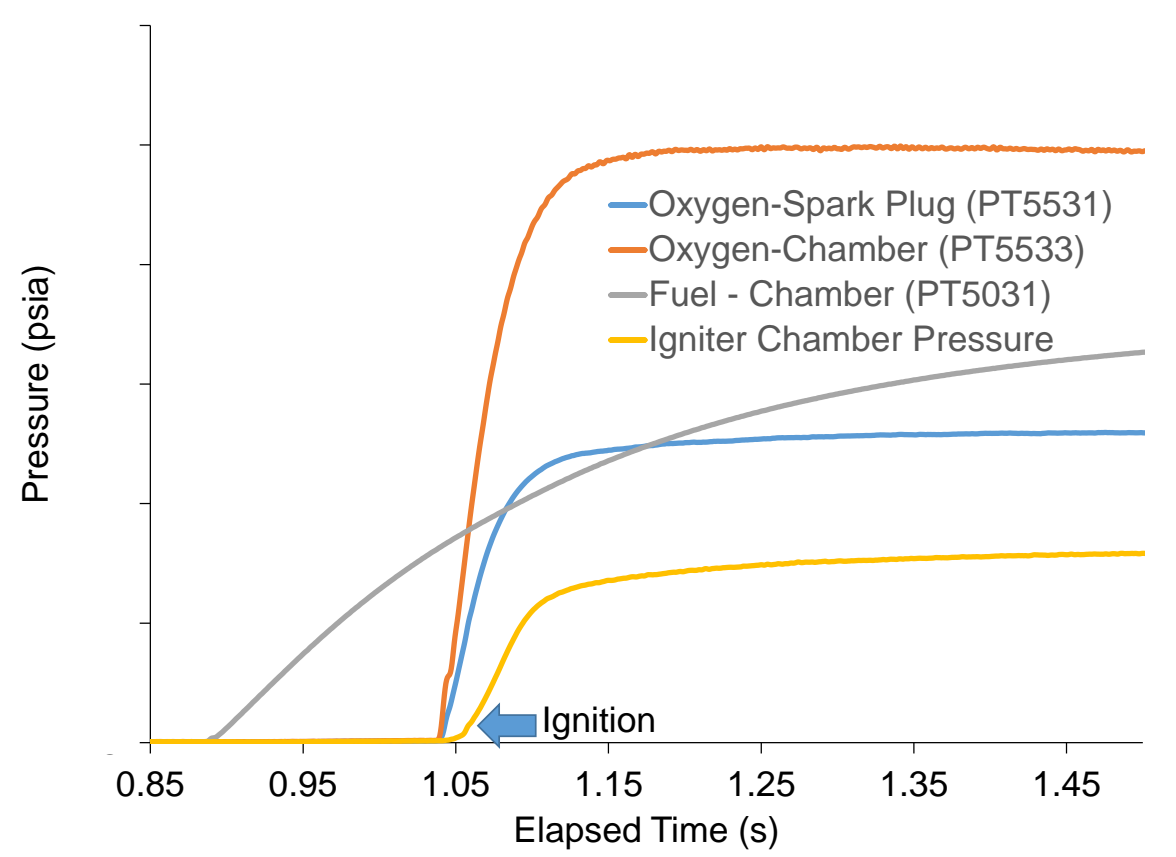

Figure 15: Plot of ASI manifold and chamber pressure vs. time for $150 \mathrm{~ms}$ fuel lead timing during GRC tests (GRC Tests - Run 716) 


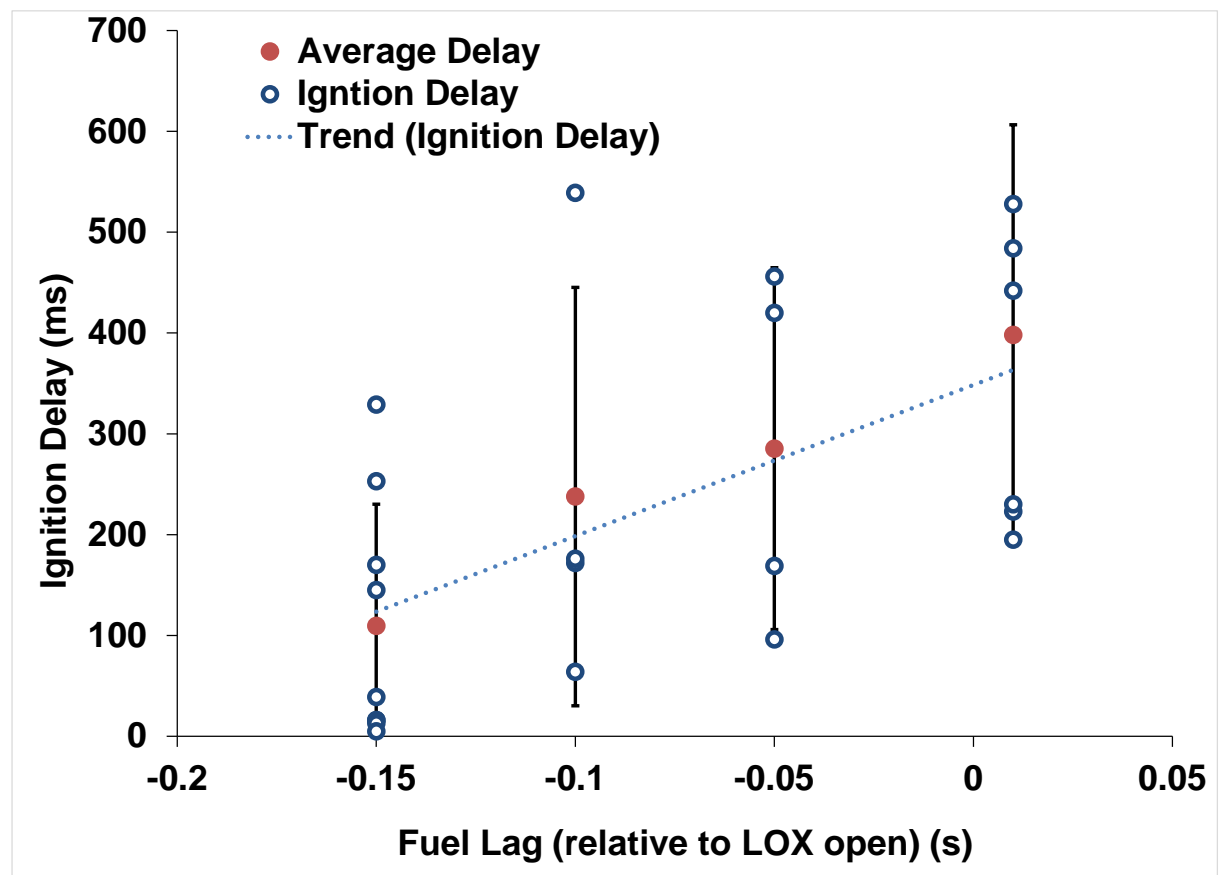

Figure 16: Plot of ignition delay vs. fuel lag (relative to LOX open) for GRC tests (Test Day 5 only)

igniter and set conditions, it took nearly $150 \mathrm{~ms}$ for the fuel to sufficiently fill and pressurize the manifold of the igniter in order to see short $(<50 \mathrm{~ms})$ ignition delays. However, this is not the only factor to consider, as MSFC testing also showed some variability in ignition delay (250-560 ms) in MSFC Test Series 1 despite having the more favorable 150 ms fuel lead.

Drawing conclusions from the data to definitively state what parameter is causing the ignition delay differences seen between MSFC and GRC data is not possible. While the MSFC data was conducted at sea-level, the GRC data is largely conducted at altitude. This difference could account for some ignition delay characteristics seen in GRC data because the igniter would require a little more time to have sufficient gas flow into the combustion chamber for ignition. In the vacuum environment, sufficient pressure needs to build to enable Paschen breakdown, while sealevel tests would have atmospheric pressure air or nitrogen available to ionize. Some variability was still seen in ignition delay for sea-level testing at GRC that was not apparent in MSFC testing. Comparison of the GRC data to MSFC data at sea-level conditions is not necessarily fair, given post-test understanding of timing, as the GRC data at sea-level was using the less favorable fuel lag conditions, which would hamper ignition even at sea-level. This could at least partially account for the discrepancy, since GRC sea-level tests had a potential fuel-starved condition to overcome. The authors recommend repeating tests at sea-level conditions with similar timing to determine if ignition behavior is similar for identical timing conditions.

With regards to the two styles of exciters tested, the conventional exciter, with its stronger delivered spark energy (ref: Table 2), was clearly more consistent in its ability to ignite the ASI flows. However, both igniters did achieve successful ignitions under vacuum conditions. While the compact exciter was not necessarily able to consistently ignite the ASI igniter, even the conventional unit often experienced very long ignition delays on the order of $800-900 \mathrm{~ms}$ in some cases. Given the revelation of the timing issue above, under a more favorable environment where fuel was more abundant, the compact unit would have generated more ignition events. PCAD testing demonstrated that even low energy sparks, sometimes as low as 1-6 mJ, can cause ignition if the proper conditions and timing are present in the chamber. ${ }^{10}$ Test results with the compact style exciter, with its 8-mJ delivered spark energy, lend support to that conclusion. Despite the overall lack of ignitions, the compact unit did demonstrate ignition events in some cases, suggesting that the exciter design is capable of vacuum ignition in the right mixture ratio environment. This lends confidence to tests addressing the initial objective of showing that both of these exciters are capable of working within a vacuum. 


\section{Summary and Conclusions}

An augmented spark impinging (ASI) igniter developed by NASA has been used frequently and successfully as a workhorse methane engine igniter. This igniter, which employs an electrical spark exciter system, was recently tested at NASA GRC to help support internal and commercial engine development programs.

Since this igniter was to be operated under vacuum conditions, where conventional spark exciter units are prone to corona discharge effects, two exciter units suitable for vacuum operation were tested; a compact exciter system which eliminated the high voltage ignition lead of conventional units, and a modified conventional exciter with improved sealing on the ignition lead. Both exciters were tested at altitude conditions ( 0.5 psia [25 Torr]). This test program demonstrated that both units can successfully ignite the ASI igniter with oxygen/methane propellants, although the conventional unit, with its stronger spark, was able to achieve ignition more consistently under the conditions tested. Despite having a relatively weak delivered spark energy, the compact exciter did demonstrate some vacuum ignition events under the right conditions.

Testing also showed that while overall O/F of the core igniter flow had some influence on ignition potential, the transient manifold fill process was a critical factor to achieving favorable conditions for ignition and reducing ignition delay times. While the overall core mixture ratios between GRC and MSFC tests were similar, the oxidizer lead timing initially used at GRC created a fuel starved condition within this particular hardware, despite an ox lead being a successful condition for other prior programs. Once the transient aspects of the propellant timing were adjusted, more rapid and consistent ignition delay timing was observed.

In order to more fairly characterize and compare these exciters under vacuum, the authors suggest that future work with this igniter further explore the optimum fuel lead timing and test the compact exciter under the more optimal fuel lead timing conditions.

\section{Acknowledgments}

The authors gratefully thank the tireless efforts from the civil servants and contractors of the NASA Glenn Space Combustion and Materials Branch, in the Facilities, Test \& Manufacturing Directorate, who helped to conduct this test series.

A note of tremendous thanks goes to Tom Fleetwood at Champion Aerospace for providing the conventional, yet custom, exciter and ignition leads. Mr. Fleetwood also generously provided valuable technical support for the vacuum ignition tests.

Lastly, Mrs. Osborne and Mrs. Greene respectfully and gratefully acknowledge the technical contributions of the late Herman Pickens of Orion Development. Herman passed away on May 16, 2016 at the age of 83. Herman was incredibly supportive of the internal R\&D work at NASA MSFC for many years, up until his last months. His kindness, technical expertise, and enthusiasm for science and engineering will not be forgotten. His wife, Chris Pickens, also assisted in the development and production of compact exciter units used with great success in MSFC igniter and engine test programs.

The NASA igniter tests were conducted as part of the Lander Technologies project, in the Advanced Exploration Systems program of the NASA Human Exploration and Operations Mission Directorate.

\section{References}

${ }^{1}$ Chavers, D. G., Ess, K., Moore, J., Dervan, M., Ondocsin, W. P., Carson, J. M. and Johnson, W. L., "Status of NASA’s Lander Technologies Project," AIAA-2016-5221, AIAA Space 2016 Conferences and Exposition, Long Beach, CA, 13-16 September 2016, doi: 10.2514/6.2016-5221.

${ }^{2}$ Brown, T., Klem, M. and McRight, P., "Foundational Methane Propulsion Related Technology Efforts, and Challenges for Applications to Human Exploration Beyond Earth Orbit," Paper SP2016_AP4, Space Propulsion 2016, Rome, Italy, 2-6 May 2016.

${ }^{3}$ Hurlbert, E., McManamen, J. P. and Studak, J. W., "Advanced Development of a Compact 5-15 lbf Lox/Methane Thruster for an Integrated Reaction Control and Main Engine Propulsion System," AIAA-2011-6113, 47th AIAA/ASME/SAE/ASEE Joint Propulsion Conference \& Exhibit, San Diego, CA, 31 July - 03 August 2011, doi: 10.2514/6.2011-6113.

${ }^{4}$ Hurlbert, E., Angstadt, T., Villemarette, M., Collins, J., Allred, J., Mahoney, J. and Peters, T., "870 lbf Reaction Control System Tests using LOx/Ethanol and LOx/Methane at White Sands Test Facility," AIAA 2008-5247, 44 ${ }^{\text {th }}$ AIAA/ASME/SAE/ASEE Joint Propulsion Conference and Exhibit, Hartford, CT, July 21-23, 2008, doi: 10.2514/6.2008-5247. 
${ }^{5}$ Smith, T. D., Klem, M. D. and Fisher, K., "Propulsion Risk Reduction Activities for Non-Toxic Cryogenic Propulsion," AIAA 2010-8680 (also published as: NASA TM-2010-216820), AIAA Space 2010 Conference and Exhibit, Anaheim, CA, 30 August 2 September 2010, doi: 10.2514/6.2010-8680.

${ }^{6}$ Robinson, P. J., Veith, E. M. and Turpin, A. A., "Test Results for a Non-Toxic Dual Thrust Reaction Control Engine," AIAA 2005-4457, 41st AIAA/ASME/SAE/ASEE Joint Propulsion Conference \& Exhibit, Tucson, AZ, 10 - 13 July 2005.

${ }^{7}$ Schneider, S. J., John, J. W. and Zoeckler, J. G., "Design, Fabrication, and Test of a LOX/LCH4 RCS Igniter at NASA," NASA TM 2007-215038 (Also published as AIAA 2007-5442), National Aeronautics and Space Administration, Cleveland, OH, 2007.

${ }^{8}$ Breisacher, K. and Ajmani, K., "LOX/Methane Main Engine Igniter Tests and Modeling," AIAA 2008-4757 (Also NASA TM 2008-215421), 44 ${ }^{\text {th }}$ AIAA/ASME/SAE/ASEE Joint Propulsion Conference and Exhibit, Hartford, CT, July 21-23, 2008.

${ }^{9}$ Kleinhenz, J., Sarmiento, C. and Marshall, W., "Experimental Investigation of Augmented Spark Ignition of a LO2/LCH4 Reaction Control Engine at Altitude Conditions," NASA TM-2012-217611, National Aeronautics and Space Administration, Cleveland, OH, 2012.

10 Marshall, W. M. and Kleinhenz, J. E., "Analysis of 100-lbf (445-N) LO2-LCH4 Reaction Control Engine Impulse Bit Performance," NASA TM-2012-217613, National Aeronautics and Space Administration, Cleveland, OH, 2012.

${ }^{11}$ Robinson, J. W., "Liquid Oxygen/Liquid Methane Component Technology Development at MSFC," SP2010_1826775, Space Propulsion 2010, San Sebastian, Spain, May 3-6, 2010.

12 McManamen, J. P., Hurlbert, E. A. and Kroeger, D. J., "Development and Flight Operation of a 5 lbf to $20 \mathrm{lbf}$ O2/CH4 Roll Control Engine for Project Morpheus," AIAA-2014-3589, AIAA Propulsion and Energy Forum, Cleveland, OH, July 28-30, 2014, doi: $10.2514 / 6.2014-3589$.

${ }^{13}$ Hurlbert, E., Morehead, R., Melcher, J. C. and Atwell, M., "Integrated Pressure-Fed Liquid Oxygen / Methane Propulsion Systems - Morpheus Experience, MARE, and Future Applications," AIAA 2016-4681, AIAA Propulsion and Energy Forum, Salt Lake City, UT, July 25-27, 2016, doi: 10.2514/6.2016-4681.

${ }^{14}$ Atwell, M. J., Hurlbert, E. A., Melcher, J. C. and Morehead, R. L., "Thermal Vacuum Testing of ICPTA RCS at Plum Brook B-2," Poster presented at the Pathways Beyond Low Earth Orbit In-Space Chemical Propulsion Technical Interchange Meeting, Huntsville, AL, 4-6 April 2017.

${ }^{15}$ Atwell, M. J., Hurlbert, E. A., Melcher, J. C. and Morehead, R. L., "Pressure-Fed LOX/LCH4 Reaction Control System for Spacecraft: Transient Modeling and Thermal Vacuum Hotfire Test Results," (submitted for publication), AIAA Propulsion and Energy Forum, Atlanta, GA, 10-12 July 2017.

${ }^{16}$ Melcher, J. C., Atwell, M. J., Morehead, R. L., Hurlbert, E. A., Bugarin, L. and Chaidez, M., "Coil-On-Plug Ignition for Oxygen/Methane Liquid Rocket Engines in Thermal Vacuum Environments," (submitted for publication), AIAA Propulsion and Energy Forum, Atlanta, GA, 10-12 July 2017.

${ }^{17}$ Hill, G. M., Weaver, H. F., Kudlac, M. T., Maloney, C. T. and Evans, R. K., "Space Propulsion Research Facility (B-2): An Innovative, Multi-Purpose Test Facility," NASA TM-2011-217007, National Aeronautics and Space Administration, Cleveland, $\mathrm{OH}, 2011$.

${ }^{18}$ Kudlac, M. T., Weaver, H. F. and Cmar, M. D., "NASA Plum Brook’s B-2 Test Facility: Thermal Vacuum and Propellant Test Facility," NASA TM-2012-217234, National Aeronautics and Space Administration, Cleveland, OH, 2012.

${ }^{19}$ Huzel, D. K. and Huang, D. H., Eds., Progress in Astronautics and Aeronautics Series, A. R. Seebass, Series Ed., American Institute of Aeronautics and Astronautics, Washington, D.C., 1992, ISBN: 1-56347-013-6.

${ }^{20}$ Meyer, M. L., Arrington, L. A., Kleinhenz, J. E. and Marshall, W. M., "Testing of a Liquid Oxygen/Liquid Methane Reaction Control Thruster in a New Altitude Rocket Engine Test Facility," NASA TM-2012-217643, National Aeronautics and Space Administration, Cleveland, OH, 2012.

${ }^{21}$ Kubiak, J. M. and Arnett, L. A., "Green Propellant Test Capabilities of the Altitude Combustion Stand at the NASA Glenn Research Center," JANNAF PIB, 11th Modeling \& Simulation, 9th Liquid Propulsion, 8th Spacecraft Propulsion Joint Subcommittee Meeting, Phoenix, AZ, 5-8 December 2016. 
${ }^{22}$ Skaff, A., Grasl, S., Nguyen, C., Hockenberry, S., Schubert, J., Arrington, L. and Vasek, T., "Liquid Methane/Liquid Oxygen Propellant Conditioning Feed System (PCFS) Test Rigs," JANNAF $3^{\text {rd }}$ Spacecraft Propulsion System Joint Subcommittee Meeting, Orlando, FL, December 8-12, 2008. 


\section{Appendix}

Table 3: Test Conditions for Check-out Day and Test Day 1

\begin{tabular}{|c|c|c|c|c|c|c|c|}
\hline Test Day & Run No. & Exciter & $\begin{array}{l}\text { Fuel Lag } \\
\text { (ms) }\end{array}$ & Ignition & $\begin{array}{l}\text { Ignition } \\
\text { Delay } \\
\text { (ms) }\end{array}$ & $\begin{array}{c}\text { Target O/F } \\
(\sim)\end{array}$ & $\begin{array}{l}\text { O/F Core - } \\
\text { TE5x11 ( ) }\end{array}$ \\
\hline \multirow{4}{*}{$\begin{array}{l}\text { Check- } \\
\text { out Day }\end{array}$} & 608 & \multirow{4}{*}{ Compact } & \multirow{4}{*}{10} & $\mathrm{~N} / \mathrm{A}$ & \multicolumn{3}{|c|}{ Facility Abort } \\
\hline & 609 & & & N/A & \multicolumn{3}{|c|}{ Facility Abort } \\
\hline & 610 & & & $\mathrm{~N} / \mathrm{A}$ & \multicolumn{3}{|c|}{ Facility Abort } \\
\hline & 611 & & & No & & 41.5 & 44.40 \\
\hline \multirow{18}{*}{$\begin{array}{c}\text { Test Day } \\
1\end{array}$} & 615 & \multirow{5}{*}{ Compact } & \multirow{5}{*}{10} & No & & 41.5 & 35.28 \\
\hline & 616 & & & No & & 41.5 & 33.56 \\
\hline & 617 & & & Yes & 504 & 45.6 & 4.49 \\
\hline & 618 & & & No & & 47.6 & 4.71 \\
\hline & 619 & & & No & & 47.6 & 33.46 \\
\hline & 620 & \multirow{13}{*}{ Conventional } & 10 & No & & 47.6 & 5.43 \\
\hline & 621 & & \multirow{2}{*}{0} & No & & 47.6 & 6.05 \\
\hline & 622 & & & No & & 47.6 & 6.43 \\
\hline & 623 & & \multirow{2}{*}{40} & $\mathrm{~N} / \mathrm{A}$ & \multicolumn{3}{|c|}{ Facility Abort } \\
\hline & 624 & & & No & & 47.6 & 46.19 \\
\hline & 625 & & \multirow{8}{*}{10} & Yes & 460 & 45.6 & 6.69 \\
\hline & 626 & & & No & & 45.6 & 6.22 \\
\hline & 627 & & & No & & 41.5 & 5.35 \\
\hline & 628 & & & Yes & 278 & 30.4 & 3.59 \\
\hline & 629 & & & Yes & 547 & 30.4 & 3.58 \\
\hline & 630 & & & Yes & 139 & 30.4 & 3.64 \\
\hline & 631 & & & Yes & 223 & 28.4 & 25.00 \\
\hline & 632 & & & Yes & 484 & 28.4 & 3.25 \\
\hline
\end{tabular}


Table 4: Test Conditions for Test Day 2

\begin{tabular}{|c|c|c|c|c|c|c|c|}
\hline Test Day & Run No. & Exciter & $\begin{array}{l}\text { Fuel Lag } \\
\text { (ms) }\end{array}$ & Ignition & $\begin{array}{c}\text { Ignition } \\
\text { Delay } \\
\text { (ms) }\end{array}$ & $\begin{array}{c}\text { Target O/F } \\
(\sim)\end{array}$ & $\begin{array}{l}\text { O/F Core - } \\
\text { TE5x11 ( ) }\end{array}$ \\
\hline \multirow{16}{*}{$\begin{array}{c}\text { Test Day } \\
2\end{array}$} & 633 & \multirow{16}{*}{ Conventional } & \multirow{16}{*}{10} & No & & 30.4 & 27.86 \\
\hline & 634 & & & Yes & 263 & 30.4 & 28.01 \\
\hline & 635 & & & Yes & 778 & 30.4 & 27.65 \\
\hline & 636 & & & No & & 30.4 & 27.52 \\
\hline & 637 & & & Yes & 118 & 30.4 & 28.08 \\
\hline & 638 & & & Yes & 358 & 30.4 & 27.97 \\
\hline & 639 & & & Yes & 865 & 30.4 & 28.03 \\
\hline & 640 & & & Yes & 258 & 25.3 & 23.29 \\
\hline & 641 & & & $\mathrm{~N} / \mathrm{A}$ & \multicolumn{3}{|c|}{ Facility Abort } \\
\hline & 642 & & & Yes & 219 & 25.3 & 23.30 \\
\hline & 643 & & & Yes & 431 & 25.3 & 23.26 \\
\hline & 644 & & & Yes & 226 & 25.3 & 22.51 \\
\hline & 645 & & & Yes & 195 & 23.1 & 16.17 \\
\hline & 646 & & & Yes & 230 & 23.1 & 17.41 \\
\hline & 647 & & & Yes & 442 & 23.1 & 18.54 \\
\hline & 648 & & & Yes & 528 & 23.1 & 18.88 \\
\hline
\end{tabular}


Table 5: Test Conditions for Test Day 3

\begin{tabular}{|c|c|c|c|c|c|c|c|}
\hline Test Day & Run No. & Exciter & $\begin{array}{l}\text { Fuel Lag } \\
\text { (ms) }\end{array}$ & Ignition & $\begin{array}{c}\text { Ignition } \\
\text { Delay } \\
\text { (ms) }\end{array}$ & $\begin{array}{c}\text { Target O/F } \\
(\sim)\end{array}$ & $\begin{array}{l}\text { O/F Core - } \\
\text { TE5x11 ( ) }\end{array}$ \\
\hline \multirow{17}{*}{$\begin{array}{c}\text { Test Day } \\
3\end{array}$} & 651 & \multirow{17}{*}{ Compact } & \multirow{15}{*}{10} & No & & 30.4 & 27.11 \\
\hline & 652 & & & No & & 30.4 & 27.53 \\
\hline & 653 & & & No & & 30.4 & 27.28 \\
\hline & 654 & & & No & & 25.3 & 22.93 \\
\hline & 655 & & & $\mathrm{~N} / \mathrm{A}$ & \multicolumn{3}{|c|}{ Facility Abort } \\
\hline & 656 & & & No & & 45.6 & 17.19 \\
\hline & 657 & & & No & & 45.6 & 31.74 \\
\hline & 658 & & & Yes & 882 & 45.6 & 33.68 \\
\hline & 659 & & & No & & 45.6 & 35.75 \\
\hline & 660 & & & No & & 41.5 & 33.68 \\
\hline & 661 & & & No & & 41.5 & 34.27 \\
\hline & 662 & & & $\mathrm{~N} / \mathrm{A}$ & \multicolumn{3}{|c|}{ Facility Abort } \\
\hline & 663 & & & No & & 39.8 & 33.64 \\
\hline & 664 & & & Yes & 840 & 39.8 & 34.36 \\
\hline & 665 & & & No & & 39.8 & 35.41 \\
\hline & 666 & & \multirow{2}{*}{20} & No & & 39.8 & 36.99 \\
\hline & 667 & & & No & & 39.8 & 37.60 \\
\hline
\end{tabular}


Table 6: Test Conditions for Test Day 4 (Sea-Level Testing)

\begin{tabular}{|c|c|c|c|c|c|c|c|}
\hline Test Day & Run No. & Exciter & $\begin{array}{l}\text { Fuel Lag } \\
\text { (ms) }\end{array}$ & Ignition & $\begin{array}{c}\text { Ignition } \\
\text { Delay } \\
\text { (ms) }\end{array}$ & $\begin{array}{c}\text { Target O/F } \\
(\sim)\end{array}$ & $\begin{array}{l}\text { O/F Core - } \\
\text { TE5x11 ( ) }\end{array}$ \\
\hline \multirow{23}{*}{$\begin{array}{c}\text { Test Day } \\
4 \text { (Sea- } \\
\text { Level) }\end{array}$} & 668 & \multirow{11}{*}{ Compact } & \multirow{11}{*}{10} & Yes & 767 & 30.4 & 27.09 \\
\hline & 669 & & & No & & 30.4 & 27.34 \\
\hline & 670 & & & No & & 30.4 & 27.49 \\
\hline & 671 & & & No & & 41.5 & 36.64 \\
\hline & 672 & & & Yes & 394 & 41.5 & 36.22 \\
\hline & 673 & & & No & & 41.5 & 35.77 \\
\hline & 675 & & & Yes & 531 & 41.5 & 31.66 \\
\hline & 676 & & & No & & 41.5 & 33.92 \\
\hline & 677 & & & No & & 41.5 & 34.84 \\
\hline & 678 & & & No & & 30.4 & 26.40 \\
\hline & 679 & & & No & & 30.4 & 26.70 \\
\hline & 682 & \multirow{12}{*}{ Conventional } & \multirow{12}{*}{10} & Yes & 587 & 41.5 & 35.28 \\
\hline & 683 & & & Yes & 201 & 41.5 & 36.08 \\
\hline & 684 & & & Yes & 413 & 41.5 & 36.10 \\
\hline & 685 & & & Yes & 254 & 45.6 & 39.10 \\
\hline & 686 & & & Yes & 403 & 45.6 & 39.57 \\
\hline & 687 & & & Yes & 247 & 45.6 & 39.30 \\
\hline & 688 & & & Yes & 241 & 30.4 & 27.14 \\
\hline & 689 & & & Yes & 244 & 30.4 & 27.36 \\
\hline & 690 & & & Yes & 208 & 30.4 & 27.37 \\
\hline & 691 & & & Yes & 484 & 25.3 & 22.99 \\
\hline & 692 & & & Yes & 115 & 25.3 & 22.99 \\
\hline & 693 & & & Yes & 494 & 25.3 & 22.95 \\
\hline
\end{tabular}


Table 7: Test Conditions for Test Day 5

\begin{tabular}{|c|c|c|c|c|c|c|c|}
\hline Test Day & $\begin{array}{l}\text { Run } \\
\text { No. }\end{array}$ & Exciter & $\begin{array}{l}\text { Fuel } \\
\text { Lag } \\
\text { (ms) }\end{array}$ & Ignition & $\begin{array}{c}\text { Ignition } \\
\text { Delay } \\
\text { (ms) }\end{array}$ & $\begin{array}{c}\text { Target O/F } \\
(\sim)\end{array}$ & $\begin{array}{l}\text { O/F Core - } \\
\text { TE5x11 ( ) }\end{array}$ \\
\hline \multirow{24}{*}{ Test Day 5} & 696 & \multirow{24}{*}{ Conventional } & \multirow{7}{*}{10} & Yes & 560 & 41.5 & 36.74 \\
\hline & 697 & & & Yes & 261 & 41.5 & 36.54 \\
\hline & 698 & & & Yes & 258 & 41.5 & 36.56 \\
\hline & 699 & & & Yes & 394 & 41.5 & 36.59 \\
\hline & 700 & & & No & & 41.5 & 36.58 \\
\hline & 701 & & & No & & 41.5 & 36.60 \\
\hline & 702 & & & No & & 41.5 & 36.62 \\
\hline & 703 & & \multirow{4}{*}{-50} & Yes & 420 & 41.5 & 36.62 \\
\hline & 704 & & & Yes & 96 & 41.5 & 36.52 \\
\hline & 705 & & & Yes & 456 & 41.5 & 36.48 \\
\hline & 706 & & & Yes & 169 & 41.5 & 36.39 \\
\hline & 707 & & \multirow{4}{*}{-100} & Yes & 172 & 41.5 & 36.37 \\
\hline & 708 & & & Yes & 64 & 41.5 & 36.19 \\
\hline & 709 & & & Yes & 539 & 41.5 & 36.15 \\
\hline & 710 & & & Yes & 176 & 41.5 & 36.20 \\
\hline & 711 & & \multirow{9}{*}{-150} & Yes & 39 & 41.5 & 36.24 \\
\hline & 712 & & & Yes & 16 & 41.5 & 36.20 \\
\hline & 713 & & & Yes & 16 & 41.5 & 36.32 \\
\hline & 714 & & & Yes & 170 & 41.5 & 36.33 \\
\hline & 715 & & & Yes & 145 & 41.5 & 36.39 \\
\hline & 716 & & & Yes & 13 & 41.5 & 36.43 \\
\hline & 717 & & & Yes & 329 & 41.5 & 36.42 \\
\hline & 718 & & & Yes & 253 & 41.5 & 36.44 \\
\hline & 719 & & & Yes & 5 & 41.5 & 36.50 \\
\hline
\end{tabular}

